\title{
Responses of acrylamide-treated rat bladders
}

\author{
Nurullahoglu-Atalik E ${ }^{1}$, Okudan $\mathrm{N}^{2}$, Belviranli $\mathrm{M}^{2}$, Esen $\mathrm{H}^{3}$, Yener $\mathrm{Y}^{4}$, Celik ${ }^{5}$ \\ Department of Pharmacology, Meram Faculty of Medicine, Necmettin Erbakan University, Konya, Turkey. \\ esraatalik@hotmail.com
}

\begin{abstract}
Objective: Acrylamide (ACR) is a chemical used in many industries around the world and more recently was found to be formed naturally in foods cooked at high temperatures. ACR was shown to be a neurotoxicant, reproductive toxicant, and carcinogen in animal species. The aim of the present study is to evaluate the influence of $\mathrm{ACR}$ treatment on urinary bladder responses to carbachol $\left(10^{-9}-3 \times 10^{-4} \mathrm{M}\right)$ and potassium chloride $(\mathrm{KCl}$; 5-100 mM), each of them causes receptor-dependent and receptor-independent contractions, respectively. We also examined the role of gender in these responses.

Material and methods: Rats of both genders were divided into three groups as follows: (1) Control animals (2) ACR-I; ACR-treated (2 mg/kg-d for 90 days) (3) ACR-II; ACR-treated (5 mg/kg-d for 90 days).

Results: In rats treated with $\mathrm{ACR}$, the $\mathrm{EC}_{50}$ values of carbachol and $\mathrm{KCl}$, but not the maximal response, to both agents were significantly higher than in control group. Histopathological parameters such as edema, congestion, inflammatory cells, microvascular proliferation, fibrosis, eosinophils, mast cells and epithelial damage were all higher in the ACR-treated group than in the controls.

Conclusions: These results demonstrate for the first time that ACR-treatment can induce urinary bladder injury (Tab. 4, Fig. 4, Ref. 30). Full Text in PDF www.elis.sk.

Key words: acrylamide, bladder, carbachol, contractions, gender, $\mathrm{KCl}$.
\end{abstract}

Acrylamide (ACR) is a vinyl monomer used worldwide for the production of polyacrylamides (EPA, 2009). Polyacrylamides are primarily used as flocculants for treating industrial waste water or municipal drinking water (1-4). They are also used for manufacturing dyes, adhesives, as a pulp/paper thickening agent, in oil recovery, and as chemical grouts in tunnels, sewers, and wells $(1,4)$. The low molecular weight and high water solubility of ACR enable this compound to easily pass through various biological membranes (5-7). For this reason, all tissues are theoretically targets for acrylamide carcinogenesis. Acrylamide is a chemical product formed when frying, roasting, grilling or baking carbohydrate-rich foods at temperatures above 120 degrees C. Acrylamide is thus found in a number of foods, such as bread, crisps, French fries and coffee. Tobacco smoking also generates substantial amounts of acrylamide. Acrylamide is rapidly ingested and largely distributed to different body tissues despite urinary excretion. Most of ACR iss eliminated in urine mainly as conjugates with urinary mercapturic acids (8). Data on toxicity for human mainly come from data from workers, who are exposed through air and skin. Daily exposure to

${ }^{1}$ Department of Pharmacology, ${ }^{3}$ Pathology, Meram Faculty of Medicine, ${ }^{4}$ Faculty of Education, Department of Biology Education, Necmettin Erbakan University, ${ }^{2}$ Department of Physiology, Faculty of Medicine, ${ }^{5}$ Department of Histology and Embryology, Faculty of Veterinary Medicine, Selcuk University, Konya, Turkey

Address for correspondence: K. Esra Nurullahoglu-Atalik, Dept of Pharmacology, Meram Faculty of Medicine, University of Necmettin Erbakan, Konya, 42080, Turkey.

Fax: +90.332 .2237124$
ACR through oral or intraperitoneal route at doses between 0.5 and $50 \mathrm{mg} / \mathrm{kg}$ /day has been associated with neurological toxicity in different animal species $(9,10)$. The majority of animal studies to date have involved subchronic ACR administration $(<90$ days exposure) at relatively high daily dose-rates (milligram per kilogram per day) via the i.p. or oral (gavage, drinking water) route (9).

Although gender differences in responsiveness of the bladder to muscarinic stimulation have been reported $(11,12)$, the effects of ACR-treatment due to gender differences have not been investigated on rat urinary bladder. Our aim was to study the effects of ACR on the detrusor smooth muscle contractility, by giving ACR in the drinking water of rats for 90 days. The relationships between functional changes and structural damage in the treated bladder were also investigated in both genders.

\section{Materials and methods}

\section{Animals and husbandry}

Male and female weaned Wistar rats, weighing 65-75 g and aged 3-4 weeks, were obtained from Selcuk University Experimental Medicine Research and Application Centre (Konya, Turkey). The rats were housed in wire-topped opaque polycarbonate cages and maintained under constant environmental conditions with a $12 \mathrm{~h}$ light/dark schedule. The environmental temperature was $20 \pm 2{ }^{\circ} \mathrm{C}$ and humidity was $50 \%$. Commercial food pellets and drinking water were provided ad libitum. The protocols of the animal experiments were approved by the internal ethical commitee of the agency. 


\section{Experimental design}

Male and female Wistar rats were included in this experiment. Animals of each gender were segregated into three groups each contained 6 animals. Two of them were treatment groups and one of them was a control group. ACR was administered to the treatment groups at 2 and $5 \mathrm{mg} / \mathrm{kg} \mathrm{b}$.w./day via drinking water for 90 days. Tap water was administered to control group in the same manner as in the treatment groups. Body weights of rats were measured in all groups before and 90 days after ARC treatment.

All animals were sacrificed $24 \mathrm{~h}$ after the last treatment by cervical dislocation. The lower abdomen was opened, the urinary bladders were exposed and placed in a petri dish containing Krebs-Henseleit solution (KHS, mM: $\mathrm{NaCl} 119, \mathrm{KCl} 4.70, \mathrm{MgSO}_{4} 1.50, \mathrm{KH}_{2} \mathrm{PO}_{4}$ $1.20, \mathrm{CaCl}_{2} 2.50, \mathrm{NaHCO}_{3} 25$, Glucose 11) with the connective tissues cut out. Changes in isometric tension were recorded by a force-displacement transducer(BIOPAC MP36, Santa Barbara, California, USA) connected through amplifiers to a ITBS08 Integrated Tissue Bath System (Commat, Ankara, Turkey). Starting from each baldder, a single detrusor strip ( $2 \times 10 \mathrm{~mm})$ was prepared for in vitro investigations and a second one was sent for pathological research.

\section{Organ baths}

The bladder strip was mounted at $0.5 \mathrm{~g}$ tension in a $25 \mathrm{ml}$ organ bath containing KHS mantained at $37{ }^{\circ} \mathrm{C}$ and aerated with $95 \% \mathrm{O}_{2}$ and $5 \% \mathrm{CO}_{2}$. Tissues were allowed to equilibrate for $1 \mathrm{~h}$. Then cumulative concentration-response curves were determined for carbachol $\left(10^{-8}-3 \times 10^{-4} \mathrm{M}\right)$.

In another part of the study, the tissues were contracted with $\mathrm{KCl}(5-100 \mathrm{mM})$. This procedure was repeated for each group. Only one agent was tested in each preparation $(n=6)$ from three different rat groups.

\section{Histochemical examinations}

Urinary bladder segments $(n=6)$ were used for histopathological assessments. Studies were performed on strips separated prior
Tab. 1. EC50 values for carbachol (Car) and $\mathrm{KCl}$ of rat urinary bladder. ACR-I; 2 mg/kg ACR-treated, ACR-II; 5 mg/kg ACR-treated. Each value is derived from six experiments. Data are means $\pm \mathrm{SEM}$.

\begin{tabular}{lccccc}
\hline & \multicolumn{2}{c}{ Male } & & \multicolumn{2}{c}{ Female } \\
\cline { 2 - 3 } \cline { 5 - 6 } & Car $\left(\times 10^{-6} \mathrm{M}\right)$ & $\mathrm{KCl}\left(\times 10^{-2} \mathrm{M}\right)$ & & $\operatorname{Car}\left(\times 10^{-6} \mathrm{M}\right)$ & $\mathrm{KCl}\left(\times 10^{-2} \mathrm{M}\right)$ \\
\hline Control & $2.5 \pm 0.1$ & $4.3 \pm 0.1$ & & $0.8 \pm 0.3$ & $3.2 \pm 0.1$ \\
ACR-I & $1.6 \pm 0.1^{\mathrm{a}}$ & $2.8 \pm 0.1^{\mathrm{a}}$ & & $0.5 \pm 0.1^{\mathrm{a}}$ & $2.3 \pm 0.2^{\mathrm{a}}$ \\
ACR-II & $0.8 \pm 0.2^{\mathrm{a}, \mathrm{b}}$ & $2.1 \pm 0.2^{\mathrm{a}, \mathrm{b}}$ & & $0.2 \pm 0.1^{\mathrm{a}, \mathrm{b}}$ & $1.5 \pm 0.3^{\mathrm{a}, \mathrm{b}}$ \\
\hline
\end{tabular}

${ }^{\mathrm{a}} \mathrm{p}<0.05$ compared to control, ${ }^{\mathrm{b}} \mathrm{p}<0.05$ compared to ACR-I

Tab. 2. $\mathrm{E}_{\text {max }}$ (g) values carbachol and $\mathrm{KCl}$ of rat urinary bladder. ACRI; 2 mg/kg ACR-treated, ACR-II; 5 mg/kg ACR-treated. Each value is derived from six experiments. Data are means \pm SEM.

\begin{tabular}{lccccc}
\hline & \multicolumn{2}{c}{ Male } & & \multicolumn{2}{c}{ Female } \\
\cline { 2 - 3 } \cline { 5 - 6 } & $\mathrm{Car}\left(\times 10^{-6} \mathrm{M}\right)$ & $\mathrm{KCl}\left(\times 10^{-2} \mathrm{M}\right)$ & & $\mathrm{Car}\left(\times 10^{-6} \mathrm{M}\right)$ & $\mathrm{KCl}\left(\times 10^{-2} \mathrm{M}\right)$ \\
\hline Control & $1.1 \pm 0.1$ & $1.3 \pm 0.1$ & & $1.2 \pm 0.1$ & $1.4 \pm 0.1$ \\
ACR-I & $1.2 \pm 0.1$ & $1.4 \pm 0.1$ & & $1.3 \pm 0.1$ & $1.5 \pm 0.1$ \\
ACR-II & $1.3 \pm 0.2$ & $1.5 \pm 0.2$ & & $1.4 \pm 0.2$ & $1.6 \pm 0.2$ \\
\hline
\end{tabular}

to the organ chamber experiments, fixed immediately in formalin $(10 \%)$ and processed using histopathological procedures for subsequent paraffin embedding. Tissues were then sectioned at 5 $\mu \mathrm{m}$, stained with either hematoxylin-eosin (HE) for morphological evaluation, Masson trichrome (for the examination of fibrosis) and Toluidine Blue (to show mast cells), by a pathologist. The preparations were examined using a light microscope, for edema, congestion, inflammatory cells, microvascular proliferation, fibrosis, eosinophils, mast cells and epithelial damage. Histopathological findings were scored on a scale of 0 (normal) to 3 (severe changes).

\section{Chemicals}

Acrylamide (Cas 79-06-1) was received from Sigma Aldrich Chemical Company. The material was a white odourless crystalline solid, with a chemical purity of $>99 \%$ (for electrophoresis). The test material was prepared weakly and stored at room temperature. All chemicals used in experiments were obtained from Sigma Chemical (St. Louis, MO, USA).

Tab. 3. Comparison of histological damage of male rat bladders median (min-max).

\begin{tabular}{|c|c|c|c|c|c|c|c|c|}
\hline & Edema & Congestion & $\begin{array}{c}\text { Inflammatory } \\
\text { cells }\end{array}$ & $\begin{array}{l}\text { Microvascular } \\
\text { proliferation }\end{array}$ & Fibrosis & Eosinophil & Mast cells & $\begin{array}{c}\text { Epithelial } \\
\text { damage }\end{array}$ \\
\hline $\begin{array}{l}\text { Control } \\
\text { (GI) }\end{array}$ & $0(0-0)$ & $0(0-0)$ & $0(0-0)$ & $0(0-0)$ & $0(0-0)$ & $0(0-0)$ & $0(0-0)$ & $0(0-0)$ \\
\hline $\begin{array}{l}\text { ACR } \\
2 \mathrm{mg} / \mathrm{kg} \text { (GII) }\end{array}$ & $1.2^{*}(1-2)$ & $1.2^{*}(1-2)$ & $0.5^{*}(0-1)$ & $0.4(0-1)$ & $0.2(0-1)$ & $0.5(0-1)$ & $0.8(0-1)$ & $0(0-0)$ \\
\hline $\begin{array}{l}\text { ACR } \\
5 \mathrm{mg} / \mathrm{kg}(\mathrm{GIII})\end{array}$ & $1.7^{*}(1-2)$ & $1.3^{*}(1-2)$ & $1.3^{*}(1-2)$ & $1.3^{*}(1-2)$ & $1.2^{*}(1-2)$ & $1.5^{*}(1-2)$ & $1.5^{*}(1-3)$ & $0.7^{*}(0-1)$ \\
\hline
\end{tabular}

" $\mathrm{p}<0.05$ compared with control group

Tab. 4. Comparison of histological damage of female rat bladders median (min-max).

\begin{tabular}{|c|c|c|c|c|c|c|c|c|}
\hline & Edema & Congestion & $\begin{array}{c}\text { Inflammatory } \\
\text { cells }\end{array}$ & $\begin{array}{c}\text { Microvascular } \\
\text { proliferation }\end{array}$ & Fibrosis & Eosinophil & Mast cells & $\begin{array}{c}\text { Epithelial } \\
\text { damage }\end{array}$ \\
\hline $\begin{array}{l}\text { Control } \\
\text { (GI) }\end{array}$ & $0(0-0)$ & $0(0-0)$ & $0(0-0)$ & $0(0-0)$ & $0(0-0)$ & $0(0-0)$ & $0(0-0)$ & $0(0-0)$ \\
\hline $\begin{array}{l}\text { ACR } \\
2 \mathrm{mg} / \mathrm{kg}(\mathrm{GII})\end{array}$ & $1^{*}(1-2)$ & $1.2^{*}(1-2)$ & $0.8^{*}(0-1)$ & $0.3(0-1)$ & $0(0-0)$ & $0.5^{*}(0-1)$ & $0.8(0-1)$ & $0(0-0)$ \\
\hline $\begin{array}{l}\text { ACR } \\
5 \mathrm{mg} / \mathrm{kg} \text { (GIII) }\end{array}$ & $1.8^{*}(1-3)$ & $1.8^{*}(1-3)$ & $2^{*}(1-3)$ & $2^{*}(1-3)$ & $1^{*}(1-2)$ & $2^{*}(1-3)$ & $2^{*}(1-3)$ & $1^{*}(1-2)$ \\
\hline
\end{tabular}




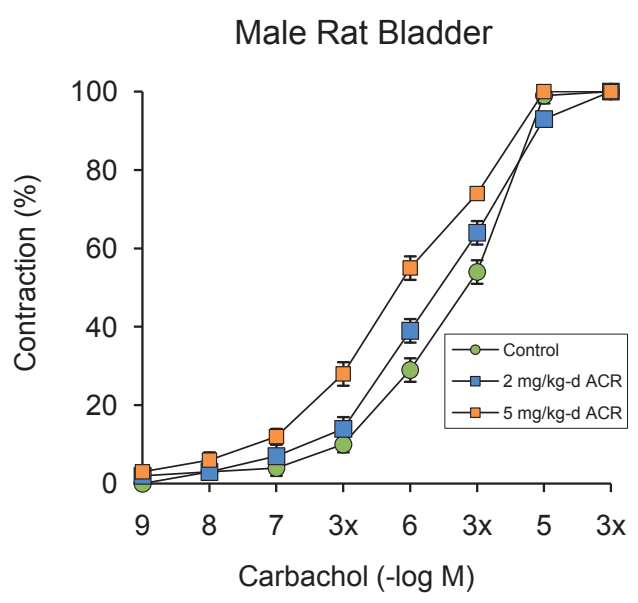

Fig. 1. Carbachol concentration-response curves of control, $2 \mathrm{mg} / \mathrm{kg}$-d (ACR-I) and $5 \mathrm{mg} / \mathrm{kg}-\mathrm{d}$ (ACR-II) ACR-treated male rat bladder. Each point is the mean $\pm S E$ of 6 experiments.

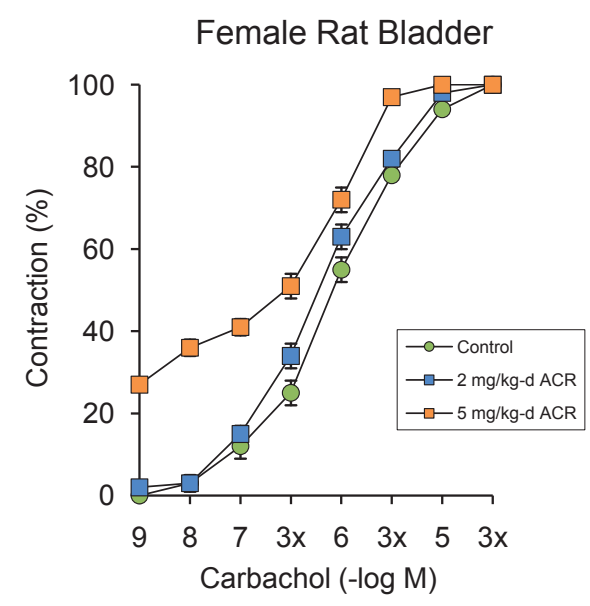

Fig. 2. Carbachol concentration-response curves of control, $2 \mathrm{mg} / \mathrm{kg}-\mathrm{d}$ (ACR-I) and $5 \mathrm{mg} / \mathrm{kg}-\mathrm{d}$ (ACR-II) ACR-treated female rat bladder. Each point is the mean $\pm S E$ of 6 experiments.

\section{Statistical analysis}

Concentrations of the contractile agents causing $50 \%$ of the maximal response $\left(\mathrm{EC}_{50}\right)$ were calculated from each individual concentration-response curve. Maximal responses and $\mathrm{EC}_{50}$ values for curves obtained from control and ACR $(2 \mathrm{mg} / \mathrm{kg})$-treated or control and ACR $(5 \mathrm{mg} / \mathrm{kg})$-treated and in both gender (between two groups) were compared by using Student's $t$ test. Statistical significance was set at $\mathrm{p}<0.05$. The histopathological results were expressed as median (min-max). All numerical data were first analyzed using the nonparametric Kruskal-Wallis test (whether there was a difference between groups) and then the Mann-Whitney Utest was performed to analyze two groups consecutively.

\section{Results}

\section{Histopathologic findings}

All histological parameters are summarized in Tables 3 and 4. Control animals with histologically normal bladders were as- signed a score of " 0 " for all parameters. A comparison of control (GI) and ACR-treated; GII and GIII groups for all parameters like edema, congestion, inflammatory cells, microvascular proliferation, fibrosis, eosinophil, mast cells and epithelial damage recorded significantly higher values in GIII $(\mathrm{p}<0.05)$. Figure 5 also displayed photographic alterations in the urinary bladder.

\section{Contractile response to carbachol}

Carbachol $\left(10^{-9}-3 \times 10^{-4} \mathrm{M}\right)$ produced concentration-dependent contractions of male and female rat urinary bladder (Figs 1 and 2). Treatment with ACR significantly enhanced the sensitivity of the preparations to carbachol, when compared to the control in both gender (Tab. 2).

In both genders, treatment with ACR significantly enhanced the sensitivity of the preparations towards carbachol, but not maximum response, as compared with the control group. The sensitiv-

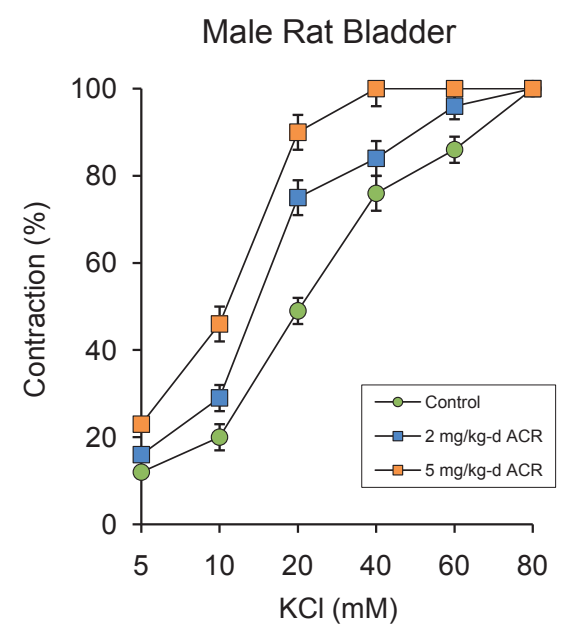

Fig. 3. KCl concentration-response curves of control, $2 \mathrm{mg} / \mathrm{kg}$-d (ACRI) and $5 \mathrm{mg} / \mathrm{kg}$-d (ACR-II) ACR-treated male rat bladder. Each point is the mean $\pm \mathrm{SE}$ of 6 experiments.

\section{Female Rat Bladder}

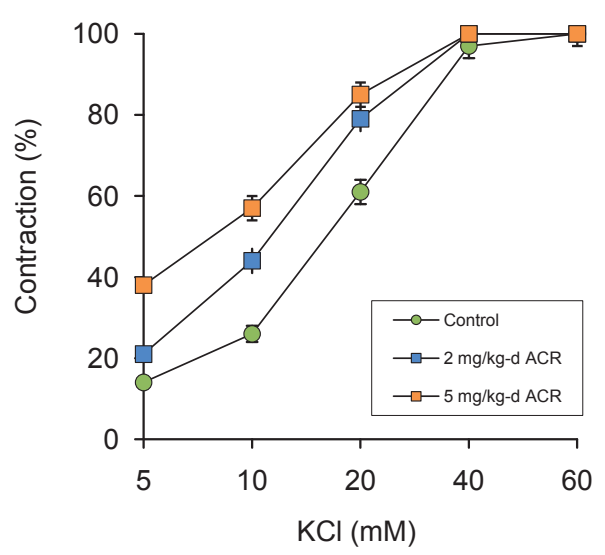

Fig. 4. KCl concentration-response curves of control, $2 \mathrm{mg} / \mathrm{kg}$-d (ACRI) and $5 \mathrm{mg} / \mathrm{kg}$-d (ACR-II) ACR-treated female rat bladder. Each point is the mean $\pm \mathrm{SE}$ of 6 experiments. 
ity of female rat urinary bladder to carbachol was higher $(\mathrm{p}<0.05)$ than male rat urinary bladder in all groups (Tab. 2).

Tables 1 and 2 show the $\mathrm{EC}_{50}$ and $\mathrm{E}_{\max }$ values of carbachol, respectively.

\section{Contractile response to $\mathrm{KCl}$}

Figures 3 and 4 show the effects of $\mathrm{KCl}(5-100 \mathrm{mM})$ in male and female rat aorta from control, Group I and Group II. In control rats of both gender, $\mathrm{KCl}$ produced concentration-dependent contractions. The sensitivity of female rat urinary bladder to $\mathrm{KCl}$ was higher $(\mathrm{p}<0.05)$ than male rat urinary bladder in all groups (Tab. 1).

In both genders, treatment with ACR; both $2 \mathrm{mg} / \mathrm{kg}-\mathrm{d}$ and $5 \mathrm{mg} / \mathrm{kg}$-d significantly enhanced the sensitivity $(\mathrm{p}<0.05)$ of the preparations towards $\mathrm{KCl}$, but not maximum response (Tab. 2), as compared with the control group.

The sensitivity of female rat urinary bladder to $\mathrm{KCl}$ was higher $(\mathrm{p}<0.05)$ than male rat urinary bladder in all groups (Tab. 2).

\section{Discussion}

In the present work, we studied the effects of ACR-treatment on male and female rat urinary bladder function and histological structure. To our knowledge, this is the first study to show the effects of ACR treatment on the contractile responses of rat urinary bladder. ACR is a chemical product formed when frying, roasting, grilling or baking carbohydrate-rich foods at temperatures above 120 degrees $\mathrm{C}$. Tobacco smoking also generates substantial amounts of acrylamide.

Urinary bladder is an elastic organ whose function is storage and subsequent release of urine. Carbachol-induced bladder contractions are mainly mediated via $\mathrm{M}_{3}$ receptor subtype and depend not only on $\mathrm{Ca}^{2+}$ release from the intracellular calcium stores but also on $\mathrm{Ca}^{2+}$ influx via L-type $\mathrm{Ca}^{2+}$ channels. The proposed cellular mechanisms for muscarinic $\mathrm{M}_{3}$ receptor-mediated contractions involve inositol trisphosphate ( $\mathrm{IP}_{3}$ )-induced and possibly $\mathrm{Ca}^{2+}$ induced $\mathrm{Ca}^{2+}$ release from intracellular stores, $\mathrm{Ca}^{2+}$ influx via nifedipine-sensitive L-type $\mathrm{Ca}^{2+}$ channels and increased sensitivity of the contractile machinery to $\mathrm{Ca}^{2+}$ via inhibition of myosin light chain phosphatase through activation of rho kinase (13-17). It is known that $\mathrm{KCl}$ stimulates $\mathrm{Ca}^{2+}$ influx through voltage-sensitive $\mathrm{Ca}^{2+}$ channels and induces contractions $(18,19)$. Potassium is commonly used as a nonselective stimulant, a depolarizer and a pharmacological tool to open a voltage-dependent $\mathrm{Ca}^{2+}$ channel.

Our results indicate that carbachol- and $\mathrm{KCl}$-induced reproducible contractions in rat urinary bladder. Compared with the control responses, in preparations obtained from ACR-pretreated rats, the sensitivity to carbachol and $\mathrm{KCl}$ was increased in both genders. The mechanism under the increased sensitivity of urinary bladder to both agents in ACR treated rats is not understood. To the best of our knowledge, no previous data on the effects of ACR-treatment on urinary bladder are available. Post and McLeod (20) showed that ACR caused an enhanced responsiveness of the cat mesenteric bed to exogenously applied phenylephrine and noradrenaline, which indicates a supersensitivity of the receptors to these agents. Further, Ralevic et al (21) reported that in rat mesenteric vessels although responses to exogenous NA appeared to be greater after ACR treatment, this was not statistically significant and responses to ATP were unaffected.

Our results also demonstrate that female rat urinary bladder preparations were more sensitive to carbachol and $\mathrm{KCl}$ than male preparations in control and ACR-treated groups. Similarly, the histopathological findings are more evident in female rat urinary bladder than male groups. The organ bath experiments demonstrated that the contractile response to the muscarinic receptor agonist carbachol was also similar in both genders with regard to agonist potency and maximum effects, and this was found both in rat and in human bladder (22). These findings are similar to those reported from murine bladder (23) but slightly different from those reported from rat bladder by other investigators (24). This mechanism appears to be reduced in female rats by the presence of endogenous or exogenous estrogen. Gender differences in vascular activity may be modulated by actions of estradiol on chloride handling and other anions in vascular smooth muscle, which may be linked to transport of $\mathrm{Ca}^{2+}$ across the vascular muscle cell membrane (25). Similarly, studies on the vascular function between males and females suggest that female sex hormones are implicated, at least in part, in the protective effects of gender on the vasculature $(26,27)$. Membrane depolarization by high $\mathrm{KCl}$ mainly stimulates $\mathrm{Ca}^{2+}$ entry from the extracellular space (28). Reports that $\mathrm{KCl}$-induced smooth muscle contraction, $\mathrm{Ca}^{2+}$ influx and $\left[\mathrm{Ca}^{2+}\right]_{\mathrm{i}}$ are greater in males than females further support possible gender differences in the $\mathrm{Ca}^{2+}$-entry mechanisms $(29,30)$. These results support our observation.

In our study, histopathological changes representing tissue damage, such as edema, congestion, inflammatory cells, microvascular proliferation, fibrosis, eosinophil, mast cells and epithelial damage, were significantly higher in bladder sections from ACRtreated rats. Especially in $5 \mathrm{mg} / \mathrm{kg}$-d ACR-treated rats.

In conclusion, the results of the present study suggest that the pretreatment with ACR increased the sensitivity to carbachol and $\mathrm{KCl}$ in both genders of rat bladder. Histopathological parameters such as edema, congestion, inflammatory cells, microvascular proliferation, fibrosis, eosinophil, mast cells and epithelial damage were all higher in the ACR-treated group than in the controls. These results demonstrate for the first time that ACR-treatment can induce urinary bladder injury. These results show that dietary ACR caused abnormalities in the experimental rats. So, we recommended that people continue to eat a balanced diet, rich in fruits and vegetables. We also advise that food should not be cooked excessively for too long time or at too high temperatures.

\section{References}

1. EPA. National primary drinking water regulations. Office of Ground Water and Drinking Water, US Environmental Protection Agency; 2009.

2. EU. Opinion of the scientific committee on food on new findings regarding the presence of acrylamide in food. Brussels: European Union; 2002. SCF/CS/CNTM/CONT/4 Final.

3. Habermann CE. Kirk-Othmer Encyclopedia of Chemical Technology. John Wiley \& Sons; 2000, p. 288-303. 
4. WHO. Acrylamide in drinking-water. WHO/SDE/WSH/03.04/7. World Health Organization; 2003.

5. Dearfield KL, Abernathy CO, Ottley MS et al. Acrylamide: its metabolism, developmental and reproductive effects, genotoxicity, and carcinogenicity. Mutat Res 1988; 195 (1): 45-77.

6. Dearfield KL, Douglas GR, Ehling UH et al. Acrylamide: a review of its genotoxicity and an assessment of heritable genetic risk. Mutat Res 1995; 330 (1-2): 71-99.

7. Friedman M. Chemistry, biochemistry, and safety of acrylamide. A review. J Agr Food Chem 2003; 51: 4504-4526.

8. Dostal A, Cajdova J, Hudeckova H. Acrylamide in biological materials and methods of the analytical determination. Bratisl Lek Listy 2011; 112 (1): 44-47.

9. LoPachin RM. The changing view of acrylamide neurotoxicity. Neurotoxicology 2004; 25 (4): 617-630.

10. Sirot V, Hommet F, Tard A et al. Dietary acrylamide exposure of the French population: Results of the second French Total Diet Study Food Chem Toxico. 2012; 3 doi: 10.1016/j.fct.2011.12.0330).

11. Chun AL, Wein AJ, Harkaway R et al. Comparison of urinary bladder function in sexually mature and immature male and female rats. J Urol 1990; 143 (6): 1267-1271.

12. Longhurst PA, Eika B, Leggett RE et al. Comparison of urinary bladder function in 6 and 24 month male and female rats. J Urol 1992; 148 (5): $1615-1620$.

13. Wu C, Bayliss M, Newgreen D et al. A comparison of the mode of action of ATP and carbachol on isolated human detrusor smooth muscle. J Urol 1999; 162: 1840-1847.

14. Fry CH, Skennerton D, Wood D et al. The cellular basis of contraction in human detrusor smooth muscle from patients with stable and unstable bladders. Urology 2002; 59: 3-12.

15. Schneider T, Fetscher $C$, Krege $S$ et al. Signal transduction underlying carbachol-induced contraction of human urinary bladder. J Pharmacol Exp Ther 2004; 309: 1148-1153.

16. Peters SLM, Schmidt M, Michel MC. Rho kinase. A target for treating urinary bladder dysfunction? Trends Pharmacol Sci 2006; 27: 492-497.

17. Rivera L, Brading AF. The role of $\mathrm{Ca}^{2+}$ influx and intracellular $\mathrm{Ca}^{2+}$ release in the muscarinc-mediated contraction of mammalian urinary bladder smooth muscle. BJU Int 2006; 98: 868-875.
18. Kregel K, Gisolfi KC. Circulatory responses to vasoconstrictor agents during passive heating in the rat. J Appl Physiol 1990; 68 (3): 1220-1227.

19. Nelson MT, Patlak JB, Worley JF et al. Calcium channels, potassium channels, and voltage dependence of arterial smooth muscle tone. Am J Physiol 1990; 259 (1): 3-18.

20. Post EJ, McLoad JG. Acrylamide autonomic neuropathy in the cat, Part 2. Effects on mesenteric vascular control. J Neurol 1977; 33: 375-385.

21. Ralevic V, Aberdeen JA, Burnstock G. Acrylamide-induced autonomic neuropathy of rat mesenteric vessels: histological and pharmacological stu1dies. J Auton Nerv System 1991; 24: 77-88.

22. Kories C, Czyborra C, Fetscher $\mathbf{C}$ et al. Gender comparison of muscarinic receptor expression and function in rat and human urinary bladder: differential regulation of $\mathrm{M}_{2}$ and $\mathrm{M}_{3}$ receptors. Naunyn Schmiedebergs Arch Pharmacol 2003; 367 (5): 524-531.

23. Choppin A. Muscarinic receptors in isolated urinary bladder smooth muscle from different mouse strains. Br J Pharmacol 2002; 137: 522-528.

24. Longhurst PA, Levendusky M. Influence of gender and the oestrous cycle on in vitro contractile responses of the rat urinary bladder to cholinergic stimulation. Br J Pharmacol 2000; 131: 177-184.

25. Zhang A, Altura BT, Altura BM. Sexual dimorphism of vascular smooth muscle responsiveness is dependent on anions and estrogen. Steroids 1991; 56 (10): 524-526.

26. Sader MA, Celermajer DS. Endothelial function, vascular reactivity and gender differences in the cardiovascular system.Cardiovasc Res 2002; 53 (3): 597-604.

27. Orshal JM, Khalil RA. Gender, sex hormones, and vascular tone. Am J Physiol Regul Integr Comp Physiol 2004; 286 (2): 233-249.

28. Khalil RA, van Breemen C. Mechanisms of calcium mobilization and homeostasis in vascular smooth muscle and their relevance to hypertension. In: Laragh JH, Brenner BM (Eds). Hypertension: Pathophysiology, Diagnosis and management. New York: Raven Press, 1995, p. 523-540.

29. Crews JK, Murphy JG, Khalil RA. Gender differences in $\mathrm{Ca}(2+)$ entry mechanisms of vasoconstriction in Wistar-Kyoto and spontaneously hypertensive rats. Hypertension 1999; 34 (4 Pt 2): 931-936.

30. Murphy JG, Khalil RA. Gender-specific reduction in contractility and $\left.\left[\mathrm{Ca}^{(2+}\right)\right]_{(\mathrm{i})}$ in vascular smooth muscle cells of female rat. Am J Physiol Cell Physiol 2000; 278 (4): 834-844. 